\title{
Controlled atmosphere maintains native and cultivated yerba mate quality during shelf life after long-term storage
}

\author{
Fabio Rodrigo Thewes*, Auri Brackmann, Erani Eliseu Schultz, Eduardo Perkovski Machado, \\ Vagner Ludwig, Luana Ferreira dos Santos \\ Universidade Federal de Santa Maria - Departamento de Fitotecnia - Santa Maria (RS), Brasil.
}

\begin{abstract}
Yerba mate shows social and economic importance for the Southern Latin American countries due to its easy production and large market range. However, there is a problem to harvest the yerba mate at the correct period and to store it until processing and marketing. Thus, the aim of this paper was to evaluate the interaction among the storage in controlled atmosphere, effect of cultivation form and shelf life period on yerba mate quality after long-term controlled atmosphere storage. The experiment was conducted in a factorial arrangement (3 controlled atmosphere conditions $\times 2$ cultivation forms $\times 4$ weeks of shelf life). Native yerba mate, stored under controlled atmosphere, showed higher chlorophyll concentration as compared to the cultivated one.
\end{abstract}

Carotenoid concentration increased up to the third week of shelf life and thereafter remained constant, if the yerba mate was stored under ambient conditions. Oxygen partial pressure lowering allows long-term yerba mate storage, keeping its quality during four shelf life weeks at $20^{\circ} \mathrm{C}$. Controlled atmosphere is an efficient technique for yerba mate quality keeping during long-term storage and shelf life, allowing the harvest of the raw material at the correct period and the maintenance of its quality until processing and marketing. The cultivation form has a significant effect on the storage and shelf life potential of yerba mate stored under controlled atmosphere.

Key words: Ilex paraguariensis, coloration, chlorophyll concentration, carotenoids, phenolic compounds.

\section{INTRODUCTION}

Yerba mate (Ilex paraguarienses) is a native plant of the Latin America, used for drinks called "chimarão" and "tererê" in Brazil, Paraguay, Argentina and Uruguay (Heck and Mejia 2007). On the other hand, yerba mate is designed to tea sachets production, especially to Europe exportation. Thus, the yerba mate need high quality throughout the year, making necessary the harvest at the correct period and storage until the marketing.

Nowadays, yerba mate harvest is carried out during the entire year, resulting in periods with low quality raw material (Prestes et al. 2014). Harvesting the raw material outside the correct period, September up to May, results in yerba mate with bitter flavor and undesired color for the consumers. Thus, one of the main challenges of the research is the

production of a technology that allows yerba mate harvest at the correct period to store it during the remaining period of the year. Early studies found that the use of laminated (Cabral-Malheiros et al. 2010) and BOPP/PEBD packets (Valduga et al. 2005) maintain higher yerba mate quality as compared to paper packets. However, this storage technology did not solve the problem, once, with this storage technique, yerba mate quality decreases significantly after 12 weeks of storage (Cabral-Malheiros et al. 2010). Therefore, it is important the development of a technology that allows harvesting yerba mate at the correct period and store it until industrialization and/or marketing.

Controlled atmosphere (CA) is a technology that needs studies, especially on yerba mate quality maintenance. The main effect of CA may be the oxygen partial pressure lowering, which results in lower phenolic oxidation, maintaining 
yerba mate quality after a long-term storage (Prestes et al. 2014). Nevertheless, the phenolic compounds are dynamic compounds, which change according to the form of pre-drying, zapecado and canchado (Isolabella et al. 2010; Valerga et al. 2012). Another study with yerba mate from different production regions and processing forms found a significant interaction among these factors and CA storage (Prestes et al. 2014). The same authors also found higher quality in yerba mate stored under CA as compared to the one stored in ambient conditions. Nevertheless, there is a lack of studies evaluating the effect of cultivation form (native or cultivated) and shelf life period after CA storage on the yerba mate quality keeping.

In this context, the aim of the present paper was to evaluate the interaction among controlled atmosphere, cultivation forms and shelf life period on yerba mate quality after long-term CA storage.

\section{MATERIALS AND METHODS}

The yerba mate raw material was obtained at commercial herbals located in São Mateus do Sul, PR, Brazil. The yerba mate leaves and branches were randomly harvested in two herbals, one native and another cultivated. Immediately after harvest, the raw material was transported to the industry Vier (yerba mate industry, Santa Rosa, RS, Brazil). At this industry, the raw material was processed according to Prestes et al. (2014). The yerba mate leaves and branches were submitted to the standard industrial processing, drying and milling, in order to obtain a yerba mate that corresponds to the commercial reality. Thereafter, the yerba mate was transported to the Federal University of Santa Maria (UFSM), RS, Brazil. Afterwards, 1-kg samples were performed and put into 20-L hermetically sealed controlled atmosphere chambers.

Four replicates of native and cultivated yerba mate were put in each storage chamber. After the sample allocation inside the chambers, they were hermetically closed and connected to a gas analyzer to determine the internal atmosphere. In the chambers, the oxygen partial pressure was changed as follows: [1] $20.9 \mathrm{kPa} \mathrm{O}_{2}+0.04 \mathrm{kPa} \mathrm{CO}_{2}$ (ambient conditions); [2] $1.0 \mathrm{kPaO}_{2}+0.04 \mathrm{kPaCO}_{2}$ and [3] $0.5 \mathrm{kPaO}_{2}+0.04 \mathrm{kPaCO}_{2}$. In order to decrease the oxygen partial pressure in the storage chambers, a flushing with nitrogen was carried out, until the set point of each treatment. The storage temperature for all treatments was $20 \pm 1{ }^{\circ} \mathrm{C}$, with relative humidity of $70 \pm 2 \%$. The storage condition maintenance was performed according to the methodology proposed by Prestes et al. (2014). Throughout the storage period (10 months), the internal atmosphere of the chambers was determined once a week, and the oxygen and carbon dioxide partial pressure was corrected, if necessary. Every time the oxygen partial pressure was lower than the set point, atmospheric air was injected in the chamber up to the desired partial pressure. On the other hand, if the carbon dioxide partial pressure was higher than the set point, it was absorbed with an automatic $\mathrm{CO}_{2}$ absorber with lime scrubber.

The yerba mate was stored in CA during 10 months, thereafter the chambers were opened and the yerba mate was maintained at $20^{\circ} \mathrm{C}$ during four weeks, aiming to simulate the shelf life period. During the four shelf life weeks, the yerba mate quality was assessed weekly in order to obtain the response of each storage condition during shelf life. Throughout the shelf life period, the following analyses were performed: (a) yerba mate color: determined with a Minolta CR 310 colorimeter, operating in the CIELAB system. Previously to the color determination, the yerba mate samples were manually sieved, with the use of test strainer with an $800 \mu \mathrm{m}$ mesh aperture, to eliminate white sticks left from the branches milling. Thereafter, the samples were stowed and compacted in Petri dishes to measure their coloration. The results were expressed in Luminosity, $a^{*}$ and $b^{\star}$ values; (b) total chlorophylls and carotenoids concentration: assessed according to the method described by Lichtenthaler (1987). Thus, the chlorophylls and carotenoids were extracted from the yerba mate with a solution of $80 \%$ acetone $(\mathrm{v} / \mathrm{v})$. The solution absorbance was obtained with a spectrophotometer (Femto, 700 plus, SP, Brazil) at 470, 647 and $663 \mathrm{~nm}$. The following expressions were used for quantification:

$$
\begin{aligned}
& \text { Total chlorophylls }=7.15\left(\text { Absorbance }_{663 \mathrm{~nm}}\right)+ \\
& +18.71 \text { (Absorbance }_{647 \mathrm{~nm}} \text { ) } \\
& \text { Chlorophyll 'a' = } \left.12.25 \text { (Absorbance }{ }_{663 \mathrm{~nm}}\right) \text { - } \\
& -2.79 \text { (Absorbance }_{647 \mathrm{~nm}} \text { ) } \\
& \text { Chlorophyll 'b' = } \left.21.50 \text { (Absorbance }{ }_{647 \mathrm{~nm}}\right)- \\
& -5.10 \text { (Absorbance }{ }_{663 \mathrm{~nm}} \text { ) } \\
& \text { Total carotenoids }=\left[1,000\left(\text { Absorbance }_{470 \mathrm{~nm}}\right)-\right. \\
& \text { - 1.82 Chlorophyll 'a' - 85.02 Chlorophyll 'b'] / } 198
\end{aligned}
$$


The chlorophyll and carotenoid concentrations were expressed in $\mu \mathrm{g} \cdot \mathrm{g}^{-1}$ of fresh weight (FW); (c) phenolic compounds: in order to obtain the phenolic compound concentration, the colorimetric Folin-Ciocalteu method was followed, as reported in Singleton et al. (1999). The phenolic compounds extraction was carried out with ethanol and the quantification obtained by a gallic acid standard curve. The solution absorbance was obtained with spectrophotometer (Femto, 700 plus, SP, Brazil) at $760 \mathrm{~nm}$. Results were expressed in $\mathrm{mg}$ of gallic acid per $\mathrm{g}$ of FW.

All data were subjected to a multivariate analysis via principal component analysis (PCA) using the GENES software. Before the multivariate analysis, data matrix was auto scaled for each variable in order to assume the same weight during analysis ( mean $=0$ and variance $=1$ ). In addition, data were assessed by ANOVA, followed by a Tukey's multiple range test $(\mathrm{p}<0.05)$ in a factorial arrangement ( 3 CA conditions $\times 2$ cultivation forms $\times 4$ shelf life weeks). This analysis was performed using the Sisvar (UFLA, Version 5.7, MG, Brazil) statistical software.

\section{RESULTS AND DISCUSSION}

In order to better visualize the treatments effect, a multivariate analysis, named principal component analysis, was carried out (Figure 1). Together, the principal component 1 (PC I) and principal component 2 (PC II) explained 97.16\% of the overall variables variation. Frizon et al. (2015) found an explanation of $99.98 \%$ by PC I and PC II for phenolic compounds of yerba mate samples from different production regions. Evaluating Figure 1a, three treatment groups are formed, as shown by the circles. Group 1 is composed by yerba mate stored under ambient condition, independently of the cultivation form; group 2 is composed by cultivated yerba mate stored either under 0.5 or $1.0 \mathrm{kPa} \mathrm{O}_{2}$ and group 3 is composed by native yerba mate stored either under 0.5 or $1.0 \mathrm{kPaO}_{2}$. These results show that yerba mate stored in ambient conditions, either native or cultivated, had similar behavior during storage and shelf life. However, under CA storage, with low oxygen partial pressure $\left(0.5\right.$ and $\left.1.0 \mathrm{kPaO}_{2}\right)$, the cultivation form shows significant effect on quality maintenance during storage and shelf life (Figure 1a). High luminosity and green color loss are related to yerba mate stored under ambient conditions $\left(20.9 \mathrm{kPa} \mathrm{O}_{2}+0.04 \mathrm{kPa} \mathrm{CO}_{2}\right)$ (Figure 1b). High chlorophyll, carotenoids and phenolic compounds are related to native yerba mate stored under $\mathrm{CA}$, independently of the shelf life period.

The PCA was extremely important to show the effect of cultivation forms on yerba mate quality maintenance, especially if it was stored in CA (Figures 1a,b). According to Figure 1, native yerba mate had higher chlorophyll concentration as compared to the cultivated one stored in CA. Perhaps the higher chlorophyll concentration in native yerba mate is a result of its cultivation in shade under other plants, resulting in higher chlorophyll accumulation in leaf

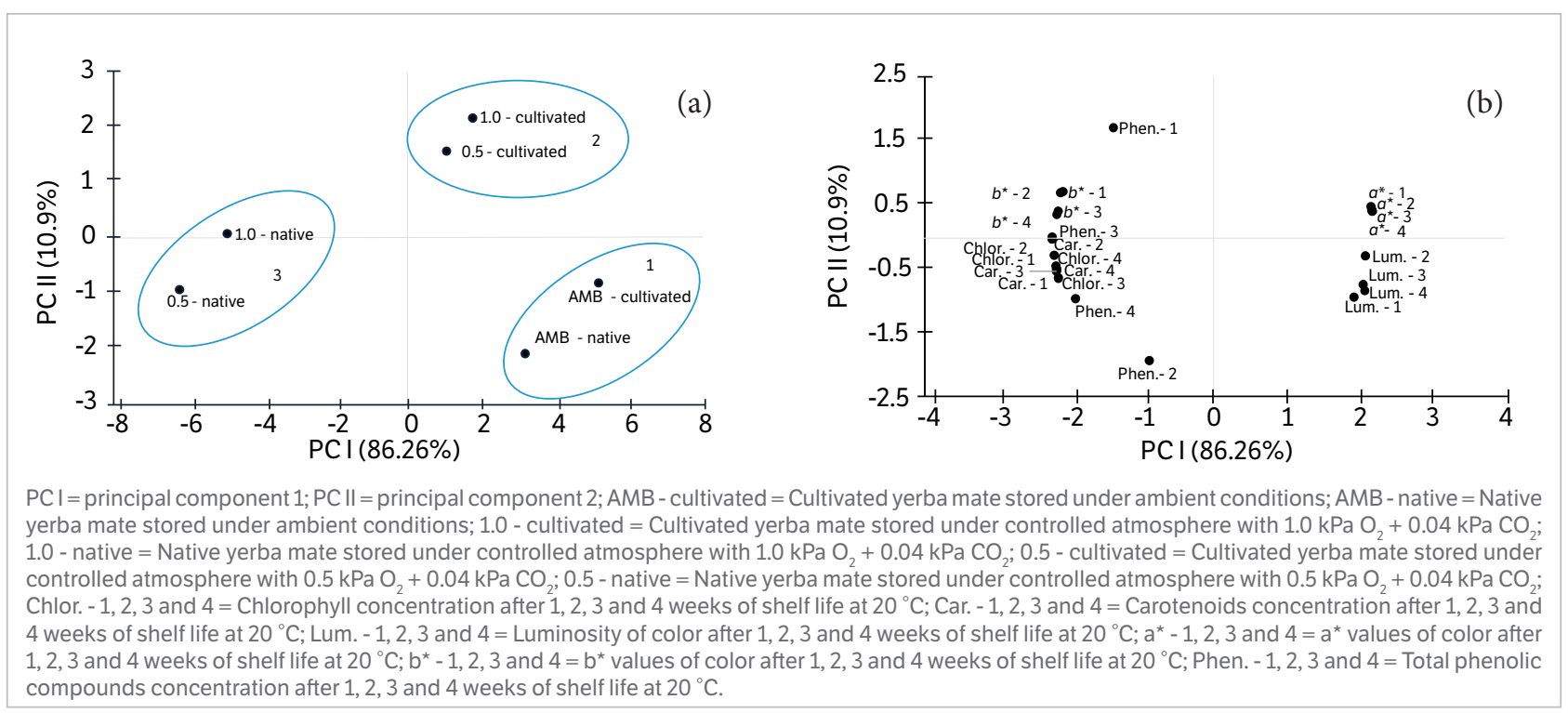

Figure 1. (a) Scores (treatments) and (b) loadings (variables) plots showing the two major principal components from the analysis of yerba mate stored under controlled atmosphere with different $\mathrm{O}_{2}$ partial pressures. 
(Table 1) in order to get the low available light. According to Taiz and Zeiger (2013), $C_{3}$ plants increase their chlorophyll concentration with shading, showing an increase in their physiology efficiency, which explains why native yerba mate had higher chlorophyll concentration. On the other hand, cultivated yerba mate is grown in open sun and did not accumulate the same chlorophyll concentration as compared to the native one.

Yerba mate coloration is a result of an interaction among some pigments present in leaves, like chlorophylls (Streit et al. 2005). In the present paper, a significant trifactorial interaction among CA storage, cultivation form and shelf life period was verified for total chlorophyll concentration (Table 1). Comparing native and cultivated yerba mate, stored under ambient condition, little differences are detected, only at two shelf life weeks, in which cultivated yerba mate showed lower chlorophyll concentration. This result shows that native yerba mate losses more chlorophyll concentration as compared to the cultivated one. This is because native yerba mate had $1,545.1 \mu \mathrm{g} \cdot \mathrm{g}^{-1}$ chlorophyll concentration as compared to $1,138.7 \mu \mathrm{g} \cdot \mathrm{g}^{-1}$ in the cultivated one at harvest. However, if the same comparison is performed for yerba mate stored under $\mathrm{CA}$, either with 0.5 or $1.0 \mathrm{kPa} \mathrm{O}$, during four shelf life weeks, native yerba mate showed the highest chlorophyll concentration. These results confirm that native yerba mate has higher storage and shelf life potential as compared to the cultivated one in CA, but in ambient conditions native and cultivated yerba mate showed similar storage potential, as shown by the PCA (Figure 1a).

Concerning the four shelf life weeks, there is a clear trend to decrease down to the second shelf life week and thereafter an increase happens in the chlorophyll concentration, independently of the cultivation form and storage condition (Table 1). This result is contradictory to the ones of the literature, which reported an exponential chlorophyll reduction with storage period (Morawicki et al. 1999). However, another research, carried out with yerba mate stored in two commercial packages, verified a similar response in total chlorophyll concentration during 12 storage weeks, when a reduction in chlorophyll concentration happened until the sixth storage week and thereafter a significant increase in chlorophyll concentrations occurred (Cabral-Malheiros et al. 2010). The same authors explained the increase in chlorophyll content due to the formation, during storage, of other compounds that had a comparable absorbance to the chlorophyll molecule. Perhaps the same change happened during shelf life after storage under CA in the present research,

Table 1. Chlorophyll concentration of native and cultivated yerba mate after 10 months of storage under controlled atmosphere at the temperature of $20^{\circ} \mathrm{C}$ plus four weeks of shelf life. Santa Maria, Brazil, 2015.

\begin{tabular}{|c|c|c|c|c|c|c|}
\hline \multirow{2}{*}{\multicolumn{2}{|c|}{ Treatments }} & \multicolumn{4}{|c|}{ Shelf life at $20^{\circ} \mathrm{C}$ (weeks) } & \multirow{2}{*}{ Mean } \\
\hline & & 1 & 2 & 3 & 4 & \\
\hline & & \multicolumn{5}{|c|}{ Chlorophyll $\left(\mu g \cdot g^{-1}\right)$} \\
\hline \multirow{2}{*}{$\mathrm{AMB}^{(2)}$} & Native $^{(3)}$ & $657.3 \mathrm{aAB}$ & $557.6 a B$ & $657.8 \mathrm{aAB}$ & 694.1aA & 641.7 \\
\hline & Cultivated & $629.8 \mathrm{aA}^{(1)}$ & 431.1bB & $586.2 \mathrm{aA}$ & $721.4 a \mathrm{~A}$ & 592.1 \\
\hline \multirow{2}{*}{0.5} & Native & $1,849.4 \mathrm{aA}$ & $1,652.4 \mathrm{aB}$ & $1,901.8 \mathrm{aA}$ & $1,820.4 \mathrm{aA}$ & $1,807.8$ \\
\hline & Cultivated & $1,233.9 \mathrm{bAB}$ & $818.8 b \mathrm{~b}$ & $1,292.9 b A$ & $1,123.4 b B$ & $1,117.3$ \\
\hline \multirow{2}{*}{1.0} & Native & $1,772.3 \mathrm{aAB}$ & $1,503.6 \mathrm{aC}$ & $1,904.1 \mathrm{aA}$ & $1,675.3 \mathrm{aB}$ & $1,712.8$ \\
\hline & Cultivated & $1,052.2 \mathrm{bAB}$ & $923.7 \mathrm{bB}$ & $1,182.9 \mathrm{bA}$ & $1,126.1 \mathrm{bA}$ & $1,071.2$ \\
\hline \multirow{3}{*}{ Native } & AMB & $657.3 b$ & $557.6 c$ & $657.8 b$ & $694.1 \mathrm{c}$ & 641.7 \\
\hline & 0.5 & $1,849.4 a$ & $1,652.4 a$ & $1,901.8 \mathrm{a}$ & $1,820.4 a$ & $1,807.8$ \\
\hline & 1.0 & $1,772.3 a$ & $1,503.6 b$ & $1,904.1 a$ & $1,675.3 b$ & $1,712.8$ \\
\hline \multirow{3}{*}{ Cultivated } & AMB & $629.8 c$ & $431.1 \mathrm{~b}$ & $586.2 b$ & $721.4 b$ & 592.1 \\
\hline & 0.5 & $1,233.9 a$ & $818.8 a$ & 1,292.9a & $1,123.4 a$ & $1,117.3$ \\
\hline & 1.0 & $1,052.2 b$ & $923.7 a$ & 1,182.9a & 1,126.1a & $1,071.2$ \\
\hline \multicolumn{2}{|c|}{ CV (\%) } & & & 6.31 & & \\
\hline
\end{tabular}

${ }^{(1)}$ Means followed by equal letters, lowercase in the columns and uppercase in the lines, do not differ by Tukey's test, at $5 \%$ probability; (2) Storage conditions adopted during storage: ambient conditions (AMB) $-\left(20.9 \mathrm{kPaO}_{2}+0.04 \mathrm{kPa} \mathrm{CO}_{2}\right) ; 0.5\left(0.5 \mathrm{kPaO}_{2}+0.04 \mathrm{kPa} \mathrm{CO}_{2}\right)$ and $1.0\left(1.0 \mathrm{kPaO} \mathrm{O}_{2}+0.04 \mathrm{kPaCO}\right) ; \mathrm{Cu}_{2} \mathrm{Cultivation}$ forms of the yerba mate: native (yerba mate naturally germinated in nature) and cultivated (yerba mate plant by man and submitted to cultural managements). Initial analysis: Chlorophyll concentration - native: $1,545.1$; cultivated: $1,138.7$. 
explaining the increase in chlorophyll concentration after two shelf life weeks.

Comparing the storage conditions in each cultivation form and shelf life period, results clearly show that yerba mate stored under ambient condition, either native or cultivated, had the lowest chlorophyll concentration during the four shelf life weeks (Table 1), without significant difference between native and cultivated yerba mate (Figure 1a). Another earlier work found lower chlorophyll concentration in yerba mate stored under ambient conditions as compared to CA (Prestes et al.2014), but this paper did not evaluate the shelf life effect on chlorophyll degradation. After one and three shelf life weeks, there was no significant difference between 0.5 and $1.0 \mathrm{kPa} \mathrm{O}_{2}$ in native yerba mate, but at the evaluation carried out after two and four shelf life weeks, yerba mate stored under the lowest oxygen partial pressure maintained higher chlorophyll concentration. On the other hand, in cultivated yerba mate, only after one shelf life week, $0.5 \mathrm{kPa} \mathrm{O}_{2}$ showed significant difference from yerba mate stored under $1.0 \mathrm{kPa} \mathrm{O}_{2}$. Prestes et al. (2014), working with higher oxygen partial pressure (1.0, 3.0, 6.0 and $20.9 \mathrm{kPa} \mathrm{O}_{2}$ ), found a significant effect of the oxygen lowering on chlorophyll maintenance, independently of the processing form and cultivation place. Probably, the better chlorophyll maintenance, by oxygen lowering, is a result of lower oxygen availability to chlorophyll oxidation, once one of the most important steps in the chlorophyll degradation pathway is the molecule oxidation (Streit et al. 2005).

Together with chlorophyll, carotenoids show a key importance on yerba mate coloration. Carotenoids are chlorophyll protector pigments, so as higher as the carotenoids concentration more protected is the chlorophyll from photooxidation (Delgado-Vargas et al. 2000). On our work, there was no significant trifactorial interaction for total carotenoids concentration (Table 2); however, there was an interaction between CA conditions, cultivation form and shelf life period. Additionally, there was a significant interaction between the cultivation form and shelf life period, independently of the CA condition. Carotenoids concentration increased until the third shelf life week and thereafter remained constant if the yerba mate was stored under ambient conditions. On the other hand, in yerba mate stored under $\mathrm{CA}$, with $0.5 \mathrm{kPa} \mathrm{O}_{2}$, it was observed an increase in carotenoid concentration until the third shelf life week and, thereafter, carotenoid concentration decreased. A reduction in carotenoid concentration happened until the second shelf life week, followed by a significant increase and another reduction at the fourth shelf life week, if the yerba mate was stored under $1.0 \mathrm{kPa} \mathrm{O}_{2}$. Comparing the CA conditions, in each evaluation time, during the entirely shelf life period, CA maintained the highest carotenoid

Table 2. Carotenoids concentration of native and cultivated yerba mate after 10 months of storage under controlled atmosphere at the temperature of $20^{\circ} \mathrm{C}$ plus four weeks of shelf life. Santa Maria, Brazil, 2015.

\begin{tabular}{|c|c|c|c|c|c|}
\hline \multirow{2}{*}{ Treatments } & \multicolumn{4}{|c|}{ Shelf life at $20^{\circ} \mathrm{C}$ (weeks) } & \multirow{2}{*}{ Mean } \\
\hline & 1 & 2 & 3 & 4 & \\
\hline & \multicolumn{5}{|c|}{ Carotenoids $\left(\boldsymbol{\mu g} \cdot \mathbf{g}^{-1}\right)$} \\
\hline $\mathrm{AMB}^{(2)}$ & $108.9 b^{(1)}$ & $145.4 \mathrm{CAB}$ & $190.7 \mathrm{bA}$ & $165.5 \mathrm{bA}$ & 152.6 \\
\hline 0.5 & $433.2 \mathrm{aC}$ & 407.2aC & $539.2 \mathrm{aA}$ & 483.9aB & 465.9 \\
\hline 1.0 & $410.6 a C$ & 361.7bD & $519.2 \mathrm{aA}$ & $459.8 \mathrm{aB}$ & 437.8 \\
\hline Mean & 317.6 & 304.8 & 416.4 & 369.7 & \\
\hline Native ${ }^{(3)}$ & $393.7 \mathrm{aC}$ & $408.9 a C$ & $507.7 a A$ & $450.8 \mathrm{aB}$ & 440.3 \\
\hline \multirow[t]{2}{*}{ Cultivated } & $241.5 b B$ & $200.6 b C$ & $325.1 \mathrm{bA}$ & $288.6 \mathrm{bA}$ & 263.9 \\
\hline & \multicolumn{2}{|c|}{ Native } & \multicolumn{2}{|c|}{ Cultivated } & \\
\hline AMB & \multicolumn{2}{|c|}{$165.6 \mathrm{bA}$} & \multicolumn{2}{|c|}{ 139.7cB } & \\
\hline 0.5 & \multicolumn{2}{|c|}{$589.9 a A$} & \multicolumn{2}{|c|}{$341.8 \mathrm{aB}$} & \\
\hline 1.0 & \multicolumn{2}{|c|}{$565.3 a A$} & \multicolumn{2}{|c|}{$310.3 b B$} & \\
\hline Mean & \multicolumn{2}{|c|}{440.3} & \multicolumn{2}{|c|}{236.9} & \\
\hline CV (\%) & \multicolumn{4}{|c|}{10.13} & \\
\hline
\end{tabular}

${ }^{(1)}$ Means followed by equal letters, lowercase in the columns and uppercase in the lines, do not differ by Tukey's test, at $5 \%$ probability; (2) Storage conditions adopted during storage: ambient conditions (AMB) $-\left(20.9 \mathrm{kPaO}_{2}+0.04 \mathrm{kPa} \mathrm{CO}_{2}\right) ; 0.5\left(0.5 \mathrm{kPaO}_{2}+0.04 \mathrm{kPa} \mathrm{CO}_{2}\right) \mathrm{and}_{1.0}\left(1.0 \mathrm{kPaO} \mathrm{O}_{2}+0.04 \mathrm{kPa} \mathrm{CO}\right.$ ); ${ }^{(3)} \mathrm{Cultivation}$ forms of the yerba mate: native (yerba mate naturally germinated in nature) and cultivated (yerba mate plant by man and submitted to cultural managements). Initial analysis: Carotenoids concentration - native: 107.9; cultivated: 92.93. 
concentration, independently of the oxygen partial pressure (Table 2). Perhaps the lower carotenoid concentration, in yerba mate stored under ambient conditions, is a result of the high oxygen partial pressure during storage $\left(20.9 \mathrm{kPa} \mathrm{O}_{2}\right)$. Thus, the carotenoid of yerba mate stored under ambient conditions was probably oxidized, once oxidation is an important carotenoid degradation pathway (Delgado-Vargas et al. 2000; Streit et al. 2005; Qian et al. 2012). Additionally, the higher carotenoids concentration in CA-stored yerba mate protected the chlorophyll molecule from oxidation during the shelf life period (Figure 1, Table 1), since carotenoids are chlorophyll protector pigments (Delgado-Vargas et al. 2000).

There was an increase in carotenoids concentration until the third shelf life week, independently of the cultivation form (native or cultivated); thereafter, a reduction was verified in native yerba mate (Table 2 ). Throughout all the shelf life period, the highest carotenoid concentration was observed in native yerba mate. Comparing the three storage conditions for native yerba mate, 0.5 and $1.0 \mathrm{kPa} \mathrm{O}$, showed similar carotenoid concentration, with higher concentration as compared to yerba mate stored under ambient conditions. Nevertheless, in cultivated yerba mate, there was significant difference among the three storage conditions, with the highest carotenoid concentration in CA with $0.5 \mathrm{kPa} \mathrm{O}_{2}$; an intermediate concentration with $1.0 \mathrm{kPa} \mathrm{O}_{2}$; and the lowest in ambient storage. These results show that carotenoids of cultivated yerba mate are more sensitive to oxidation than the ones of native yerba mate, showing that cultivated yerba mate needs to be stored under lower oxygen partial pressure and also needs more attention during yerba mate storage.

Throughout the shelf life, after long-term storage, the yerba mate coloration was darkening, independently of the storage condition and cultivation form (Table 3). Cabral-Malheiros et al. (2010) showed a significant darkening if yerba mate was stored under paper packages, but if yerba mate was stored under laminated packages an increase in its luminosity was observed. Comparing the three storage conditions for native yerba mate, the highest luminosity was verified in yerba mate stored under ambient conditions; an intermediate in CA with $1.0 \mathrm{kPa} \mathrm{O}_{2}$; and the lowest in yerba mate stored under $0.5 \mathrm{kPa} \mathrm{O}_{2}$. This result shows that the lower the oxygen partial pressure during storage, the lower the luminosity of the yerba mate after storage (Figure 1). However, for cultivated yerba mate, there was no difference among the storage conditions, with higher luminosity in relation to native in all the storage conditions, showing the oxygen lowering had no effect on cultivated yerba mate luminosity, maintaining its values close to the harvest (Table 3). Analyzing these results, the luminosity of native yerba mate, stored under CA, exhibited a darkening after storage plus four shelf life weeks, but this effect was not observed in cultivated yerba mate. Perhaps the higher luminosity of native yerba mate stored under ambient conditions as compared to CA storage is result of higher chlorophyll degradation (Table 1), resulting in colorless compounds (Streit et al. 2005), increasing the luminosity of color. The lower luminosity in CA-stored yerba mate is a result of the greener color (Table 4). Moreover, the opposite response of luminosity and green color is evidenced by the PCA (Figure 1b).

Despite the lower luminosity of native yerba mate stored under CA (Table 3), yerba mate stored under these conditions ( 0.5 and $1.0 \mathrm{kPa} \mathrm{O}_{2}$ ) showed greener color during all the shelf life period (Table 4 ). The greener color of yerba mate stored under CA is a result of higher chlorophyll concentration (Table 1), and the relationship between chlorophyll concentration and green color is confirmed by the PCA (Figure 1b). The extremely low oxygen partial pressure during CA storage ( 0.5 and $1.0 \mathrm{kPa} \mathrm{O}_{2}$ ) reduced the chlorophyll (Table 1) and carotenoids oxidation (Table 2), maintaining the characteristic yerba mate green color even after long-term

Table 3. Luminosity of native and cultivated yerba mate after 10 months of storage under controlled atmosphere at the temperature of $20^{\circ} \mathrm{C}$ plus four weeks of shelf life. Santa Maria, Brazil, 2015.

\begin{tabular}{|c|c|c|c|c|c|}
\hline \multirow{2}{*}{ Treatment } & \multicolumn{5}{|c|}{ Shelf life at $20^{\circ} \mathrm{C}$ (weeks) } \\
\hline & 1 & 2 & 3 & 4 & Mean \\
\hline \multicolumn{6}{|c|}{ Luminosity } \\
\hline $\mathrm{AMB}^{(2)}$ & 44.76 & 43.83 & 42.78 & 42.43 & $43.45 a$ \\
\hline 0.5 & 44.05 & 42.03 & 41.62 & 41.37 & $42.27 c$ \\
\hline 1.0 & 44.11 & 42.88 & 42.30 & 41.86 & $42.79 b$ \\
\hline Mean & $44.31 \mathrm{~A}^{(1)}$ & 42.91B & $42.23 \mathrm{C}$ & $41.89 \mathrm{C}$ & \\
\hline Native $^{(3)}$ & 43.44 & 42.15 & 41.55 & 41.08 & $42.06 \mathrm{~b}$ \\
\hline Cultivated & 45.17 & 43.68 & 42.91 & 42.69 & $43.61 a$ \\
\hline & \multicolumn{2}{|c|}{ Native } & \multicolumn{2}{|c|}{ Cultivated } & \\
\hline AMB & \multicolumn{2}{|c|}{$43.12 \mathrm{aB}$} & \multicolumn{2}{|c|}{$43.78 \mathrm{aA}$} & 43.45 \\
\hline 0.5 & \multicolumn{2}{|c|}{$41.10 \mathrm{cB}$} & \multicolumn{2}{|c|}{$43.43 a \mathrm{~A}$} & 42.27 \\
\hline 1.0 & \multicolumn{2}{|c|}{$41.95 \mathrm{bB}$} & \multicolumn{2}{|c|}{$43.63 a A$} & 42.79 \\
\hline Mean & \multicolumn{2}{|c|}{42.06} & \multicolumn{2}{|c|}{43.61} & \\
\hline CV (\%) & \multicolumn{5}{|c|}{1.99} \\
\hline
\end{tabular}

(1) Means followed by equal letters, lowercase in the columns and uppercase in the lines, do not differ by Tukey's test, at $5 \%$ probability; ${ }^{(2)}$ Storage conditions adopted during storage: ambient conditions (AMB) $-\left(20.9 \mathrm{kPaO}_{2}+0.04 \mathrm{kPaCO}_{2}\right)$; $0.5\left(0.5 \mathrm{kPaO}_{2}+0.04 \mathrm{kPa} \mathrm{CO}_{2}\right)$ and $1.0\left(1.0 \mathrm{kPaO}_{2}+0.04 \mathrm{kPa} \mathrm{CO}_{2}\right) ;{ }^{(3)}$ Cultivation forms of the yerba mate: native (yerba mate naturally germinated in nature) and cultivated (yerba mate plant by man and submitted to cultural managements). Initial analysis: Luminosity of color - native: 43.42 ; cultivated: 43.40 . 
storage followed by four shelf life weeks. According to the results of the literature, the most important pathway of chlorophyll degradation is the oxidation (Streit et al. 2005). Another research verified green color maintenance by storage under $\mathrm{CA}$ with low oxygen $\left(1.0 \mathrm{kPa} \mathrm{O}_{2}\right)$, but this work did not evaluate the effect of CA storage on shelf life period (Prestes et al. 2014).

Comparing native and cultivated yerba mate stored under the different conditions, greener color was identified in native yerba mate during all the shelf life period (Table 4). Throughout the shelf life, native yerba mate stored under ambient conditions showed a faster green color reduction as compared to those stored under CA, which showed a slower green color degradation. This result is because yerba mate stored under ambient condition was exposed to high oxygen partial pressures during the ten months of storage and the yerba mate stored under CA only during the four shelf life weeks after the 10 months of storage. Thereby, the green color of yerba mate stored under ambient conditions showed a significantly green color loss at chamber opening, if compared with CA stored yerba mate (Table 4). Additionally, the yerba mate stored under CA showed the highest carotenoid concentration (Table 2) that can protect the chlorophyll from oxidation (Delgado-Vargas et al. 2000), keeping the green color during the four shelf life weeks.
Native and cultivated yerba mate stored under CA with $0.5 \mathrm{kPa} \mathrm{O}_{2}$ showed greener color during the four shelf life weeks (Table 4). Prestes et al. (2014) detected greener color maintenance, by yerba mate storage in CA with $1.0 \mathrm{kPa} \mathrm{O}_{2}$ as compared to ambient storage. Nevertheless, in our research, it is proven that the oxygen lowering below $1.0 \mathrm{kPa} \mathrm{O}_{2}$ increases quality maintenance during storage and shelf life at $20^{\circ} \mathrm{C}$ (Table 4). Valduga et al. (2005), evaluating some package types, verified a loss of $68.8 \%$ in the initial green color after 120 days of storage, but in our work we found a reduction of $45.92 \%$ in native and $61.87 \%$ in cultivated yerba mate after 10 months of storage plus four shelf life weeks at $20^{\circ} \mathrm{C}$ (Table 4). This results show how efficient is CA storage on yerba mate green color maintenance as compared to traditional storage methods. Thereby, future studies should evaluate lower oxygen partial pressures in order to maintain the original harvest color with minimum green color loss.

The coordinate $b^{*}$, which ranges from yellow $(+60)$ to blue (-60) with a gray color close to zero, shows that yerba mate color became grayish during shelf life, independently of the storage conditions (Table 5). Throughout the shelf life period, yerba mate stored under ambient conditions was grayer in relation to the two CA conditions. Additionally, the cultivated yerba mate, independently of the shelf life period and storage condition, is grayer as compared to

Table 4. $a^{\star}$ values of native and cultivated yerba mate after 10 months of storage under controlled atmosphere at the temperature of $20{ }^{\circ} \mathrm{C}$ plus four weeks of shelf life. Santa Maria, Brazil, 2015.

\begin{tabular}{|c|c|c|c|c|c|c|}
\hline \multirow{2}{*}{\multicolumn{2}{|c|}{ Treatment }} & \multicolumn{5}{|c|}{ Shelf life at $20^{\circ} \mathrm{C}$ (weeks) } \\
\hline & & 1 & 2 & 3 & 4 & Mean \\
\hline & & \multicolumn{5}{|c|}{$a^{\star}$ values } \\
\hline \multirow{2}{*}{$\mathrm{AMB}^{(2)}$} & Native $^{(3)}$ & $-2.5 \mathrm{aA}$ & $-2.17 \mathrm{aB}$ & $-2.13 a B$ & $-2.27 a B$ & -2.27 \\
\hline & Cultivated & $-1.87 \mathrm{bA} \mathrm{A}^{(1)}$ & $-1.49 b B C$ & $-1.37 b c$ & $-1.56 \mathrm{bB}$ & -1.57 \\
\hline \multirow{2}{*}{0.5} & Native & $-7.33 a A$ & $-6.54 a B$ & $-6.24 a C$ & $-6.10 a C$ & -6.55 \\
\hline & Cultivated & $-4.76 b A$ & $-4.03 b B$ & $-3.78 b c$ & $-3.86 b C$ & -4.11 \\
\hline \multirow{2}{*}{1.0} & Native & $-6.73 a A$ & $-6.07 a \mathrm{~B}$ & $-5.79 a C$ & $-5.79 a C$ & -6.09 \\
\hline & Cultivated & $-4.18 \mathrm{bA}$ & $-3.68 b B$ & $-3.50 b C$ & $-3.53 b c$ & -3.72 \\
\hline \multirow{3}{*}{ Native } & AMB & $-2.5 c$ & $-2.17 c$ & $-2.13 c$ & $-2.27 c$ & -2.27 \\
\hline & 0.5 & $-7.33 a$ & $-6.54 a$ & $-6.24 a$ & $-6.10 a$ & -6.55 \\
\hline & 1.0 & $-6.73 b$ & $-6.07 b$ & $-5.79 b$ & $-5.79 b$ & -6.09 \\
\hline \multirow{3}{*}{ Cultivated } & AMB & $-1.87 b$ & $-1.49 c$ & $-1.37 c$ & $-1.56 c$ & -1.57 \\
\hline & 0.5 & $-4.76 a$ & $-4.03 a$ & $-3.78 a$ & $-3.86 a$ & -4.11 \\
\hline & 1.0 & $-4.18 b$ & $-3.68 b$ & $-3.53 b$ & $-3.53 b$ & -3.72 \\
\hline \multicolumn{2}{|c|}{ CV (\%) } & \multicolumn{4}{|c|}{2.00} & \\
\hline
\end{tabular}

${ }^{(1)}$ Means followed by equal letters, lowercase in the columns and uppercase in the lines, do not differ by Tukey's test, at $5 \%$ probability; (2)Storage conditions adopted during storage: ambient conditions (AMB) $-\left(20.9 \mathrm{kPa} \mathrm{O}_{2}+0.04 \mathrm{kPa} \mathrm{CO}\right) ; 0.5(0.5 \mathrm{kPa} \mathrm{O}+0.04 \mathrm{kPa} \mathrm{CO})$ and $1.0\left(1.0 \mathrm{kPaO}+0.04 \mathrm{kPa} \mathrm{CO}\right.$ ); ${ }_{2}^{(3)} \mathrm{Cultivation}_{2}$ forms of the yerba mate: native (yerba mate naturally germinated in nature) and cultivated (yerba mate plant by man and submitted to cultural managements). Initial analysis: $a^{\star}$ values - native: -11.28 ; cultivated: -9.26 . 
Table $5 . b^{\star}$ values of native and cultivated yerba mate after 10 months of storage under controlled atmosphere at temperature of $20^{\circ} \mathrm{C}$ plus four weeks of shelf life. Santa Maria, Brazil, 2015.

\begin{tabular}{|c|c|c|c|c|c|}
\hline \multirow{2}{*}{ Treatment } & \multicolumn{5}{|c|}{ Shelf life at $20^{\circ} \mathrm{C}$ (weeks) } \\
\hline & 1 & 2 & 3 & 4 & Mean \\
\hline & \multicolumn{5}{|c|}{$b^{\star}$ values } \\
\hline $\mathrm{AMB}^{(2)}$ & 22.71 & 22.21 & 21.46 & 21.78 & $22.04 b$ \\
\hline 0.5 & 24.06 & 23.84 & 23.33 & 23.71 & $23.74 a$ \\
\hline 1.0 & 23.93 & 23.17 & 23.29 & 23.58 & $23.49 a$ \\
\hline Mean & $23.57 A^{(1)}$ & 23.07B & $22.69 B$ & $23.02 B$ & \\
\hline Native $^{(3)}$ & 24.84 & 24.23 & 24.03 & 24.28 & $24.34 a$ \\
\hline Cultivated & 22.30 & 21.91 & 21.36 & 21.77 & $21.83 b$ \\
\hline \multirow[t]{2}{*}{ Mean } & 23.57 & 23.07 & 22.69 & 23.02 & \\
\hline & \multicolumn{2}{|c|}{ Native } & \multicolumn{2}{|c|}{ Cultivated } & \\
\hline $\mathrm{AMB}$ & \multicolumn{2}{|c|}{$22.69 \mathrm{bA}$} & \multicolumn{2}{|c|}{$21.38 \mathrm{bB}$} & 22.04 \\
\hline 0.5 & \multicolumn{2}{|c|}{$25.25 a A$} & \multicolumn{2}{|c|}{$22.23 a B$} & 23.74 \\
\hline 1.0 & \multicolumn{2}{|c|}{$25.09 a A$} & \multicolumn{2}{|c|}{$21.89 a B$} & 23.49 \\
\hline Mean & \multicolumn{2}{|c|}{24.34} & \multicolumn{2}{|c|}{21.83} & \\
\hline CV (\%) & \multicolumn{5}{|c|}{2.31} \\
\hline
\end{tabular}

${ }^{(1)}$ Means followed by equal letters, lowercase in the columns and uppercase in the lines, do not differ by Tukey's test, at $5 \%$ probability; ${ }^{(2)}$ Storage conditions adopted during storage: ambient conditions (AMB) - $\left(20.9 \mathrm{kPaO}_{2}+0.04 \mathrm{kPa} \mathrm{CO}_{2}\right)$; $0.5\left(0.5 \mathrm{kPaO}_{2}+0.04 \mathrm{kPaCO}\right)$ and $1.0\left(1.0 \mathrm{kPaO}_{2}+0.04 \mathrm{kPa} \mathrm{CO}_{2}\right) ;{ }^{(3)}$ Cultivation forms of the yerba mate: native (yerba mate naturally germinated in nature) and cultivated (yerba mate plant by man and submitted to cultural managements). Initial analysis: $b^{\star}$ values - native: 26.76 ; cultivated: 25.81 the native one. The grayer color of ambient-stored yerba mate is a result of chlorophyll degradation by phytol and $\mathrm{Mg}^{+2}$ removal from the chlorophyll molecule, resulting in the formation of a molecule named Pheophorbide, which exhibits greenish-brown coloration (Streit et al. 2005). Posteriorly, the Pheophorbide is transformed into colorless products increasing the luminosity (Table 3 ). Another paper found a positive relationship between chlorophyll concentration and $b^{*}$ values in yerba mate stored under different commercial packages (Cabral-Malheiros et al. 2010). In our research, the same response between $b^{\star}$ values and chlorophyll concentration is verified due to the closeness of these parameters in PCA (Figure 1b).

In relation to total phenolic compounds, a trifactorial interaction ( 3 CA conditions $\times 2$ cultivation forms $\times 4$ shelf life weeks) was verified (Table 6). Cultivated yerba mate stored under ambient condition and $\mathrm{CA}$ with $1.0 \mathrm{kPaO}_{2}$ showed low phenolic compounds concentration on the first shelf life week. However, after the first shelf life week, there are no significant differences between native and cultivated yerba mate. If the same comparison was carried out for yerba mate stored under CA with $0.5 \mathrm{kPaO}_{2}$, cultivated yerba mate showed low phenolic compounds after one and three shelf life weeks. The lower phenolic compounds in cultivated yerba mate probably resulted

Table 6. Phenolic compounds concentration of native and cultivated yerba mate after 10 months of storage under controlled atmosphere at temperature of $20^{\circ} \mathrm{C}$ plus four weeks of shelf life. Santa Maria, Brazil, 2015.

\begin{tabular}{|c|c|c|c|c|c|c|}
\hline \multirow{2}{*}{\multicolumn{2}{|c|}{ Treatment }} & \multicolumn{5}{|c|}{ Shelf life at $20^{\circ} \mathrm{C}$ (weeks) } \\
\hline & & 1 & 2 & 3 & 4 & Mean \\
\hline & & \multicolumn{5}{|c|}{ Phenolic compounds (mg per g) } \\
\hline \multirow{2}{*}{$\mathrm{AMB}^{(2)}$} & Native $^{(3)}$ & $182.0 \mathrm{aA}^{(1)}$ & $158.6 \mathrm{aBC}$ & $142.6 \mathrm{aC}$ & 171.7aAB & 163.7 \\
\hline & Cultivated & $119.1 b C$ & $162.3 a \mathrm{~A}$ & $138.4 \mathrm{aB}$ & $165.9 a A$ & 146.4 \\
\hline \multirow{2}{*}{0.5} & Native & 198.0aA & $171.5 \mathrm{aB}$ & $158.5 \mathrm{aB}$ & 193.1aA & 180.3 \\
\hline & Cultivated & $95.24 b C$ & 179.1aA & $144.8 \mathrm{bC}$ & $185.0 \mathrm{aA}$ & 151.1 \\
\hline \multirow{2}{*}{1.0} & Native & $186.2 \mathrm{aA}$ & 187.9aA & $156.3 \mathrm{aB}$ & $184.8 \mathrm{aA}$ & 178.8 \\
\hline & Cultivated & $77.91 b C$ & 190.9aA & $144.7 a B$ & $182.8 \mathrm{aA}$ & 149.1 \\
\hline \multirow{3}{*}{ Native } & AMB & $182.0 \mathrm{a}$ & $158.6 \mathrm{~b}$ & $142.6 a$ & $171.7 \mathrm{~b}$ & 163.7 \\
\hline & 0.5 & 198.0a & $171.5 b$ & $158.5 a$ & $193.1 \mathrm{a}$ & 180.3 \\
\hline & 1.0 & $186.2 a$ & $187.9 a$ & $156.3 a$ & $184.8 \mathrm{ab}$ & 178.8 \\
\hline \multirow{3}{*}{ Cultivated } & AMB & $119.1 a$ & $162.3 b$ & $138.4 a$ & $165.9 b$ & 146.4 \\
\hline & 0.5 & $95.24 b$ & $179.1 a$ & $144.8 a$ & $185.0 \mathrm{a}$ & 151.1 \\
\hline & 1.0 & $77.91 c$ & $190.9 a$ & $144.7 a$ & $182.8 a$ & 149.1 \\
\hline \multicolumn{2}{|c|}{ CV (\%) } & & & 5.96 & & \\
\hline
\end{tabular}

${ }^{(1)}$ Means followed by equal letters, lowercase in the columns and uppercase in the lines, do not differ by Tukey's test, at $5 \%$ probability; (2) Storage conditions adopted during storage: ambient conditions (AMB) $-\left(20.9 \mathrm{kPaO}_{2}+0.04 \mathrm{kPa} \mathrm{CO}_{2}\right) ; 0.5\left(0.5 \mathrm{kPaO}+0.04 \mathrm{kPa} \mathrm{CO}_{2}\right)$ and $1.0\left(1.0 \mathrm{kPaO}+0.04 \mathrm{kPa} \mathrm{CO}\right.$ ); $\mathrm{Ka}_{2} \mathrm{Cultivation}_{2}$ forms of the yerba mate: native (yerba mate naturally germinated in nature) and cultivated (yerba mate plant by man and submitted to cultural managements). Initial analysis: Phenolic compounds concentration - native: 185.8; cultivated: 176.2. 
in lower antioxidant capacity, once an early paper found that phenolic compound had a linear relationship with the antioxidant activity (Heck et al. 2008; Valerga et al. 2012). Additionally, the higher antioxidant activity in native yerba mate may be a result of higher carotenoids concentration (Table 2), since carotenoids can be effective antioxidants in vivo (Woodall et al. 1997). Thus, native yerba mate shows higher antioxidant potential after one shelf life week, if yerba mate is stored under ambient condition and $\mathrm{CA}$ with $1.0 \mathrm{kPaO}_{2}$, and after one and three shelf life weeks in $\mathrm{CA}$ with $0.5 \mathrm{kPaO}_{2}$ (Table 3). Comparing the shelf life period in each storage condition, there is not a clear trend to decrease or increase, but in cultivated yerba mate, phenolic compounds appear to increase during shelf life period and, in the native one, they appear to decrease or remain constant (Table 3).

In the first evaluation (one shelf life week), higher phenolic compounds were verified in cultivated yerba mate stored under ambient condition; intermediary phenolic compounds in CA with $0.5 \mathrm{kPaO}_{2}$ and the lowest in $1.0 \mathrm{kPa} \mathrm{O}_{2}$ (Table 3). There were no differences among the treatments, for native yerba mate, in the first evaluation. This result contradicted the ones of the literature, which affirm the oxygen lowering maintained higher phenolic compounds after storage (Prestes et al. 2014). However, this paper did not specify if the yerba mate was native or cultivated, explaining the difference between the results in our research. Comparing the storage condition after the first evaluation, the CA maintained similar or higher phenolic compounds as compared to ambient storage in the two cultivation forms. An early paper evidenced yerba mate to protect DNA from mutation, especially by the high antioxidant activity (Bracesco et al. 2011). Thus, yerba mate stored under CA shows more benefits for health compared to the one stored in ambient conditions.

\section{CONCLUSION}

The results of our paper show that CA is an efficient technique for yerba mate quality keeping during long-term storage and shelf life, allowing the harvest of the raw material at the correct period and the maintenance of its quality until processing and marketing. Future studies should evaluate oxygen lowering below $0.5 \mathrm{kPaO}$ to improve quality keeping during storage and extent shelf life after storage. Additionally to oxygen lowering, future studies should evaluate the combination of low oxygen with higher carbon dioxide partial pressure in order to improve yerba mate quality conservation.

The cultivation form has a significant effect on storage and shelf life potential of yerba mate stored under CA. Native yerba mate has high chlorophyll and carotenoids concentration, leading to a greener color during shelf life after storage. Cultivated yerba mate needs more care during storage to keep high quality throughout shelf life period.

Luminosity and green color decrease during shelf life, independently of the storage condition and cultivation form, but phenolic compounds of native yerba mate maintain similar values during shelf life and, in cultivated yerba mate, there is a trend to increase them after one shelf life week at $20^{\circ} \mathrm{C}$.

\section{ACKNOWLEDGEMENTS}

To Conselho Nacional de Desenvolvimento Científico e Tecnológico, Coordenação de Aperfeiçoamento de Pessoal de Nível Superior and Fundação de Amparo à Pesquisa do Estado do Rio Grande do Sul, for financial support.

\section{REFERENCES}

Bracesco, N., Sanchez, A. G., Contreras, V., Menini, T. and Gugliucci, A. (2011). Recent advances on Ilex paraguarienses research: minireview. Journal of Ethnopharmacology, 136, 378-384. http://dx.doi.org/10.1016/j.jep.2010.06.032.

Cabral-Malheiros, G., Heckheuer, L. H. R., Canto, M. W. and Balsamo, G. M. (2010). Influence of time and kind of packaging on mate during storage under ambient conditions. Ciência Rural, 40, 654-660. http://dx.doi.org/10.1590/S0103-84782010005000028.

Delgado-Vargas, F., Jiménez, A. R. and Paredes-López, O. (2000). Natural pigments: carotenoids, anthocyanins, and betalains - charachteristics, bioshyntesis, processing and stability. Critical Reviews in Food Science and Nutrition, 40, 173-289. http://dx.doi.org/10.1080/10408690091189257.

Frizon, C. N. T., Oliveira, G. A., Perusselo, C. A., Peralta-Zamora, P. G., Camlofski, A. M. O., Rossa, U. B. and Hoffmann-Ribani, R. (2015). Determination of total phenolic compounds in yerba mate (Ilex paraguarienses) combining near infrared spectroscopy (NIR) and multivariate analysis. Food Science and Technology, 60, 795-801. http://dx.doi.org/10.1016/ j.Iwt.2014.10.030. 
Heck, C. I. and Mejia, E. G. (2007). Yerba mate tea (Ilexparaguariensis): a comprehensive review on chemistry, healthy implications, and technological considerations. Journal of Food Science, 72, 138151. http://dx.doi.org/10.1111/j.1750-3841.2007.00535.x.

Heck, C. I., Schmalko, M. and González De Mejia, E. (2008). Effect of growing and drying conditions on the phenolic composition of mate teas (Ilex paraguariensis). Journal of Agricultural and Food Chemistry, 56, 8394-8403. http://dx.doi.org/10.1021/jf801748s.

Isolabella, S., Cogoi, L., López, P., Anesini, C., Ferraro, G. and Filip, R. (2010). Study of the bioactive compounds variation during yerba mate (Ilex paraguariensis) processing. Food Chemistry, 122, 695699. http://dx.doi.org/10.1016/j.foodchem.2010.03.039.

Lichtenthaler, H. K. (1987). Chlorophylls and carotenoids: pigments of photosynthetic biomembranes. Methods Enzymology, 14, 350-385.

Morawicki, R. O., Schmalko, M. E. and Känzig, R. G. (1999). Chlorophyll stability in yerba maté leaves in controlled atmospheres. Brazilian Archives of Biology and Technology, 42, 85-90.

Prestes, S. L. C., Thewes, F. R., Sautter, C. K. and Brackmann, A. (2014). Storage of yerba mate in controlled atmosphere. Ciência Rural, 44, 740-745. http://dx.doi.org/10.1590/S0103-84782014000400028.

Qian, C., Decker, E. A., Xiao, H. and Mcclements, D. J. (2012). Physical and chemical stability of b-carotene-enriched nanoemulsions: influence of $\mathrm{pH}$, ionic strength, temperature, and emulsifier type. Food Chemistry, 132, 1221-1229. http://dx.doi.org/10.1016/ j.foodchem.2011.11.091.

Singleton, V. L., Orthofer, R. and Lamuela-Raventós, R. M. (1999). Analysis of total phenols and other oxidation substrates and antioxidants by means of folin-ciocalteu reagent. Methods in Enzymology, 299, 152-178. http://dx.doi.org/10.1016/ S0076-6879(99)99017-1.

Streit, N. M., Canterle, L. P., Canto, M. W. and Hecktheuer, L. H. H. (2005). The chlorophylls. Ciência Rural, 35, 748-755. http://dx.doi.org/ 10.1590/S0103-84782005000300043.

Taiz, L. and Zeiger, E. (2013). Plant physiology. Porto Alegre: Artmed. Valduga, E., Jarvornik, G., Sordi, M. and Rezende, D. F. (2005). Evaluation of the quality of mate conditioned in different packaging materials. Brazilian Journal of Food Technology, 8, 99-105.

Valerga, J., Reta, M. and Lanari, M. C. (2012). Polyphenol input to the antioxidant activity of yerba mate (Ilex paraguariensis) extracts. Food Science and Technology, 45, 28-35. http://dx.doi.org/ 10.1016/j.Iwt.2011.07.022.

Woodall, A. A., Lee, S. W., Weesie, R. J., Jackson, M. J. and Britton, G. (1997). Oxidation of carotenoids by free radicals: relationship between structure and reactivity. Biochimica et Biophysica Acta, 1336, 33-42. 